\title{
Genetic Analysis of Some Cytoplasmic Male Sterile and Suggested Restorer Rice Lines
}

\author{
I.S. El-Degwy \\ Agronomy Dept., Faculty of Agriculture, Kafrelsheikh \\ University, Kafrelsheik, Egypt.
}

\begin{abstract}
AOUR CYTOPLASMIC Male Sterile rice (CMS) lines having diverse cytoplasmic source and ten suggested restorers beside their forty F1 rice hybrids were the materials of this study. The aim of this investigation was to study the genetic variance components, heritability and combining ability analysis in relation identifying desirable parents and hybrid for hybrid rice breeding program. The additive variance $\left(\sigma^{2} \mathrm{~A}\right)$ and the relative importance of GCA were higher for 1000-grain weight, number of panicles/ plant, number of spikelets/ panicle and heading date while the opposite was true in the rest characters. The CMS lines D297A and G46A and the restorers Wita12, Giza178 and Giza182 were the best combiners for grain yield. Yimi 15A was the best combiner for earliness. According the scale of Wang (1981) of arrangement the parent materials, G46A ranked first (compared with the other CMS lines) while wita 12 was the best combiner among all suggested restorers. Grain yield, fertility percentage and number of spikelet/ panicle recorded the highest estimates of genotypic coefficient of variability. Heritability estimates in narrow sense was relatively high for 1000-grain weight and heading date. Fertility percentage, grain yield and number of filled grain/ panicle recorded relatively higher values for the expected genetic advance from selection $(\Delta \mathrm{g} \%)$. D297A x Wita 4, G46A x Giza 181 and G46A x Giza 182 rice hybrids were distinguished combiners for grain yield and most of its components, indicating that these hybrids and their parents beside Wita12 and Giza 178 may be involved in the hybrid rice breeding program for grain yield improvment.
\end{abstract}

Rice (Oryza sativa L.) is considered one of the most important cereal crops. Enhancing productivity of rice through novel genetic approach such as hybrid rice technology is most important due to presence of cytoplasmic male sterility system in rice (Dwivedi \& Pandey, 2012). The success of a plant breeding program greatly depends upon the correct choice of parents for hybridization and the gene action of different economic traits. Choice of parental lines with high general combining (GCA) effects increases the probability of obtaining heterotic hybrids. Some selected intersubspecific hybrids have given a yield increase more than $30 \%$ over the existing inter varietals hybrids (Yuan, 1994). Combining ability analysis in rice was reported by many researchers such as Mehla et al. (2000), Gautam et al. (2012) and Gulzar \& Waseem (2012).

Correspondence e- mail: iseldegwy@yahoo.com 
Both additive and non- additive components were involved in the inheritance of most studied traits with preponderance of non-additive gene action for most of yield components (El-Degwy, 2000; Hammoud et al., 2008 and Onyia, 2012). The dominance variance was considerably more than additive variance for all the studied traits including number of panicles/ plant, grain weight, panicle length and number of fertile grains/ panicle (Hosein et al., 2013). The non-additive gene action was more important in the inheritance of number of productive tillers, number of spikelets/ panicle, spikelet fertility and grain yield (Gautam et al., 2012). Other studies showed predominance of non-additive gene action for all the studied traits (Padmavathi et al., 2012).

High heritability along with higher genetic advance were registered for grain yield, number of sterile spikelets/ panicle, fertility percentage, number of fertile grains/ panicle, number of spikelets/ panicle and 1000-grain weight indicating the preponderance of additive gene action and such characters could be improved through selection (Ghosh \& Sharma, 2012). Number of filled grains/ panicle, number of spikelets/ panicle and plant height revealed the highest genetic advance from selection (Jakkrit et al., 2013). The aim of this investigation was to study the genetic variance components, heritability and combining ability analysis in relation identifying desirable parents and hybrid for hybrid rice breeding program.

\section{Materials and Methods}

The present investigation was carried out at the Experimental Farm, Faculty of Agriculture, Kafrelsheikh University, Egypt during 2011 and 2012 seasons. Four cytoplasmic male sterile lines (CMS) with diverse cytoplasmic source; G46A (Gambica), D297A (Dissi), Yimi15A (Dian type) and V20A (Wild Abortive) were the female parents of this study. Such CMS line were crossed through Line $\mathrm{x}$ tester mating design with ten suggested restorer lines having diverse morphological and agronomical characters; namely, Sakha 106, Giza 182, Giza 178, Giza 181, Sakha 101, Wita 4, Wita 12, Gz.1368-5-4, IET1444 and Sakha 105. Details of the cytoplasmic male sterile and tester lines are presented in Table 1. All possible combination crosses were executed in a factorial mating design (lines $\mathrm{x}$ tester) in summer 2011 to produce $40 \mathrm{~F}_{1}$ seeds. Therefore, the genetic materials used in this study were 4 CMS lines and their maintainers, ten suggested restorers and $40 \mathrm{~F} 1$ seeds. The experiments were arranged in a randomized complete block design with three replications. Each replication contained 54 experimental units. The 54 genotypes were sown in plastic trays on May $4^{\text {th }}$ of 2011 . Thirty days old seedlings were individually transplanted. Each plot consisted of five rows, $3 \mathrm{~m}$ long, $20 \mathrm{~cm}$ apart and contained 15 individual plants with spacing of $20 \times 20 \mathrm{~cm}$. Routine cultural practices were done as needed similar to those used in rice production. 
TABLE 1. Parentage, cytoplasmic source, origin and plant type of the plant materials.

\begin{tabular}{|c|c|c|c|}
\hline Designation & $\begin{array}{c}\text { Parentage/cytoplasmic } \\
\text { source }\end{array}$ & Origin & $\begin{array}{c}\text { Plant } \\
\text { type }\end{array}$ \\
\hline \multicolumn{4}{|l|}{ Suggested restorers: } \\
\hline Sakha 106 & Giza 177 / Hexi 30 & ARC-Egypt & Japonica \\
\hline Giza 182 & $\begin{array}{l}\text { Giza181/IR39422-161-1-3/ } \\
\text { Giza181 }\end{array}$ & ARC-Egypt & Indica \\
\hline Giza 178 & Giza175/Miliang49 & ARC-Egypt & Indica \\
\hline Giza 181 & IR1626-203/IR28 x IR22 & ARC-Egypt & Indica \\
\hline Sakha 101 & Giza176/Miliang79 & ARC-Egypt & Japonica \\
\hline Wita 4 & --- & China & Indica \\
\hline Wita 12 & --- & China & Indica \\
\hline Gz.1368-5-4 & IR1615-31/BG94-2 & China & Indica \\
\hline IET1444 & TN1/CO29 & India & Indica \\
\hline Sakha 105 & Gz.5581/Gz.4316 & ARC-Egypt & Japonica \\
\hline \multicolumn{4}{|l|}{$\begin{array}{l}\text { Cytoplasmic male } \\
\text { sterile lines: }\end{array}$} \\
\hline G46 A & Gambica & China & Indica \\
\hline D297 A & Dissi & China & Indica \\
\hline Yimi 15 A & Dian type & China & Japonica \\
\hline V20 A & WA (Wild abortive) & China & Indica \\
\hline
\end{tabular}

Ten guarded plants from the middle row of each plot were randomly selected to measure the biometrical traits; plant height, panicle length, number of primary branches/panicle, number of spikelets/panicle, number of grains/panicle, fertility percentage, number of panicles/plant and 1000-grain weight. While, one random square meter was harvested to determine grain yield $/ \mathrm{m}^{2}$.

All measurements of the CMS lines were recorded for their iso-genic maintainers. Line x Tester analysis as described by Kempthorne (1957) was used to provide information about general and specific combining ability and to estimate various types of gene effects. Heritability was estimated as stated by Borton \& Devan (1953). The expected genetic advance from selection $(\Delta \mathrm{g})$ was calculated as stated by Johnson et al. (1955). 


\section{Results and Discussion}

\section{Test of significance}

The analysis of variance and mean squares for all the studied characters are presented in Table 2. It is clear that mean squares due to genotypes were highly significant for all the studied traits, indicating large variation among the tested genotypes for such traits. When genotypes are partitioned into parents, hybrids and parents vs. hybrids, the mean squares due to such partitions were significant or highly significant for all the studied traits. Significant mean squares of parents vs. hybrids are an indication to average heterosis over all crosses and it could be used through hybrid rice breeding program. Also, the magnitude of mean squares in parents, hybrids and parents vs. hybrids were larger several times than the corresponding error mean squares. Previous studies showed that the differences among genotypes, crosses, lines, testers and line $\times$ tester interaction were significant for all the studied traits (Gulzar \& Waseem, 2012).

\section{Combining ability}

The variations among hybrids were partitioned into lines and testers, as indicators for general combining ability (GCA), and line $\mathrm{x}$ tester interaction as indicators specific combining ability (SCA).

From the genetic view, GCA measures additive gene effects and SCA measures non-additive gene effects, including dominance and epistasis. Results in Table 2 showed that the mean squares of both general and specific combining ability variances were significant or highly significant for all the studied traits except GCA for lines for fertility percentage as it was not significant, indicating that both additive and non-additive genetic variances were important in the inheritance of these characters. However, the expected additive genetic variance appeared to be greater and more important than the non- additive genetic variance in the determining the performance of these traits.

Therefore the selection procedures based on the accumulation of additive effect would be successful in improving these traits. These results were, in general, harmony with those obtained by Hammoud et al. (2008), El-Keredy et al. (2008) and Roy \& Senapati (2012). They reported that both additive and the non-additive components were involved in governing yield and most of yield components. Previous results showed that the dominance variance was considerably more than additive variance for all studied traits including number of panicle/ plant, grain weight panicle length, plant height and number of fertile grains/ panicle (Hossein et al., 2013).

Magnitude of heterosis is determined by the combining ability of the parents. There are two types of combining ability. General combining ability (GCA) is the average performance of a parent in hybrid combination and specific combining ability (SCA) as those cases in which certain combinations are relatively better or worse. Theoretically, an estimate of GCA effects of a parent is not an absolute value. It actually depends upon the group of parents in which this particular parent was crossed in the matting system. 
GENETIC ANALYSIS OF SOME CYTOPLASMIC...

\begin{tabular}{|c|c|}
\hline 㱐 & 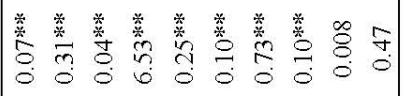 \\
\hline 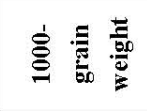 & 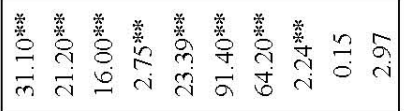 \\
\hline 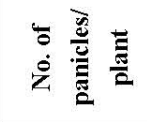 & 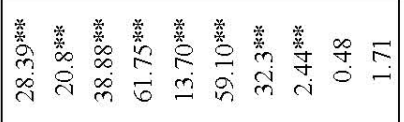 \\
\hline 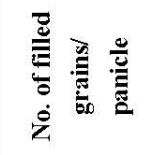 & 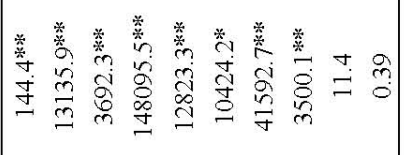 \\
\hline 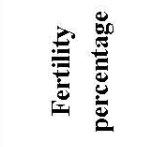 & 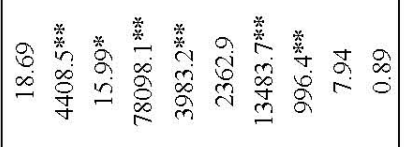 \\
\hline 흘 & 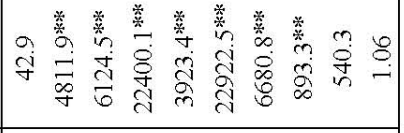 \\
\hline 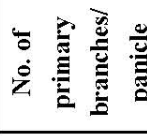 & 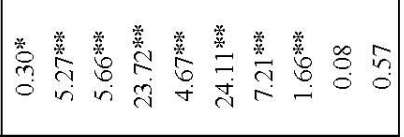 \\
\hline 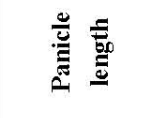 & 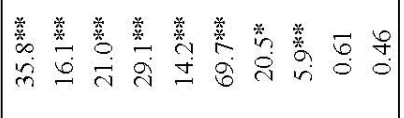 \\
\hline 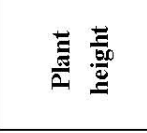 & 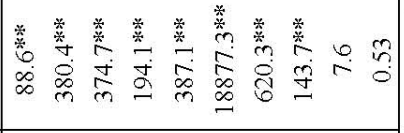 \\
\hline 产 & 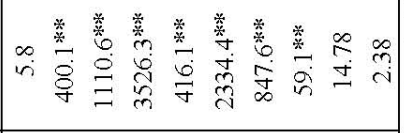 \\
\hline$\stackrel{4}{9}$ & 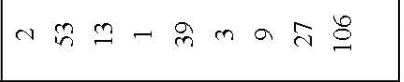 \\
\hline 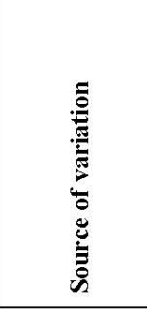 & 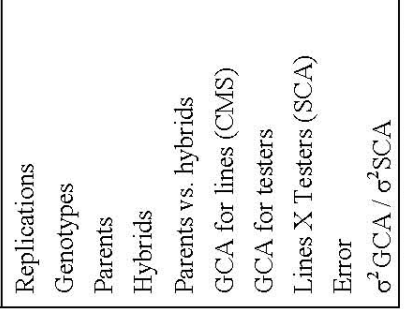 \\
\hline
\end{tabular}

Egypt. J. Agron. 35, No. 1 (2013) 
The expected estimate of (gi) would be equal zero if the parent has exactly the same average in its combinations. Significant departure from zero would indicate that the parent is much better or much poorer than the overall average of the parents involved in the study. High positive values would be interest for all traits under study except for heading date and plant height, where high negative values would be useful for plant breeder point of view.

The estimates of both GCA and SCA effects were found to be highly significant for all the studied traits (Table 3), indicating that both additive and non-additive gene action were important in the inheritance of the studied traits. Similar results were obtained by Hammoud (2004). Results presented in Table 3 showed that the CMS line Yimi 15 A had the greatest negative GCA effects $(-11.88 \pm 0.70)$ for days to $50 \%$ heading compared with the other parents. Such negative GCA effects indicate that this parent might be the best general combiner for earliness. Also, this CMS line was the second combiner for number of panicles/ plant. While the CMS line V20 A was the best general combiner for short stature plants and a good combiner for panicle length, fertility percentage and number of panicles/ plant.

The CMS line G46 A was the best general combiner for both of number of spikelets/ panicle and No. of filled grains/ panicle. Among the four CMS lines, D297 A was the best general combiner for fertility percentage and a good combiner for number of grains/ panicles and grain yield.

Regarding to suggested restorers, Sakha 106 rice cultivar was the best general combiner for number of primary branches/ panicle and 1000-grain weight and a good combiner for heading date and number of spikelets/ panicle. While, Giza 182 and Giza 178 were good combiners for heading date, fertility percentage, number of grains/ panicle and grain yield.

Among all parents, Sakha 101 recorded the highest GCA effects for number of panicles/ plant $(1.30 \pm 0.20)$ followed by Wita $4(0.88 \pm 0.20)$ while, Wita 12 was the best general combiner for panicle length, fertility percentage, number of grains/ panicle and grain yield. Gz.1368-5-4 recorded higher GCA effects for plant height compared with the other suggested restorers. IET1444 rice variety was a good combiner for heading date and number of panicles/ plant.

The GCA effects for 1000-grain weight were maximized in case of Sakha 105, Sakha 101, Giza 182 and Sakha 106 rice cultivars. Among the CMS lines, only one namely; D297 A recorded highly significant positive GCA effects for grain yield while, five suggested restorers viz. Wita 12, Giza 178, Giza 182, Gz.1368-5-4 and Giza 181 recorded highly significant GCA effects with positive value for grain yield. Such estimates were maximized in case of Wita $12(0.28$ \pm 0.03 ). Indicating that such parents might be involved in hybrid rice breeding in order to improve grain yield. 
GENETIC ANALYSIS OF SOME CYTOPLASMIC...

\begin{tabular}{|c|c|c|}
\hline 窇 & 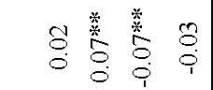 & 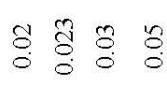 \\
\hline 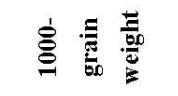 & 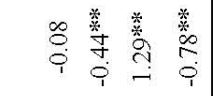 & $\stackrel{5}{0} \stackrel{0}{0} \stackrel{0}{0}$ \\
\hline 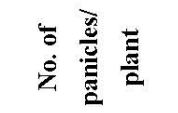 & 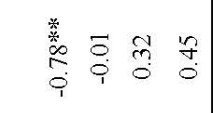 & 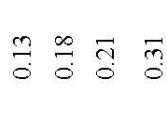 \\
\hline 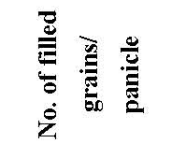 & 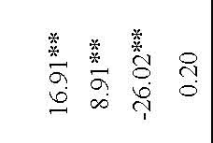 & 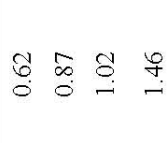 \\
\hline 窵 & 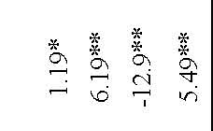 & 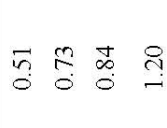 \\
\hline 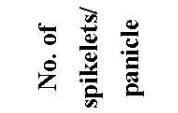 & 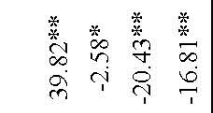 & 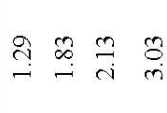 \\
\hline 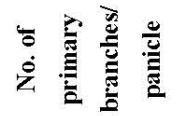 & 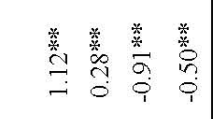 & $\begin{array}{llll}0 & 5 & 0 & 0 \\
0 & 0 & 0 & 0\end{array}$ \\
\hline 莺 & 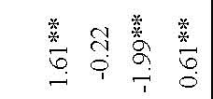 & 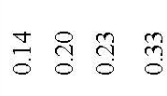 \\
\hline 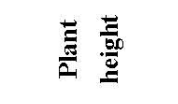 & 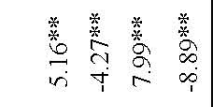 & 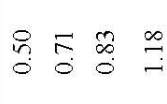 \\
\hline 胞 & 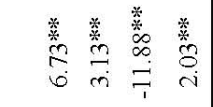 & 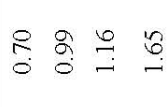 \\
\hline 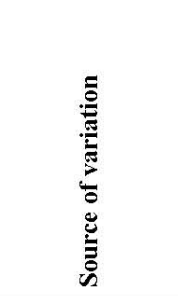 & 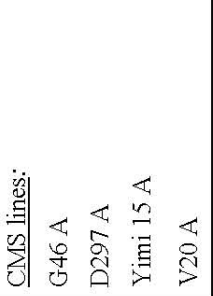 & 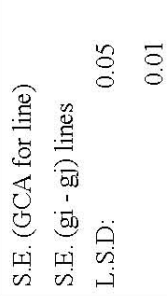 \\
\hline
\end{tabular}

Egypt. J. Agron. 35, No. 1 (2013) 


\begin{tabular}{|c|c|c|}
\hline 㱐产 & 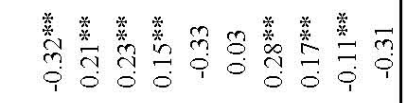 & 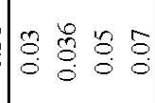 \\
\hline$\stackrel{5}{\mathrm{~s}} \cdot \frac{\mathrm{E}}{\mathrm{E}}$ & 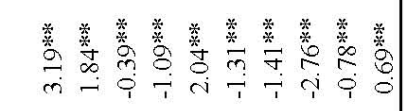 & $\exists=0$ \\
\hline 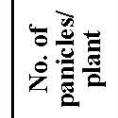 & 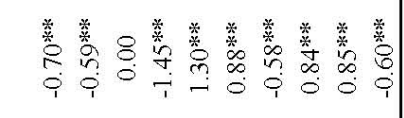 & त̂ \\
\hline 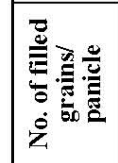 & 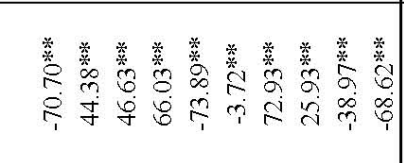 & 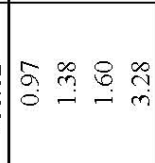 \\
\hline 焉 & 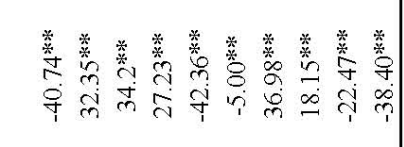 & 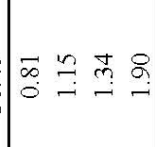 \\
\hline 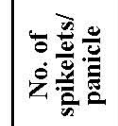 & 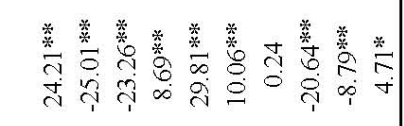 & 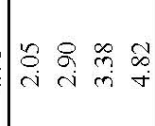 \\
\hline 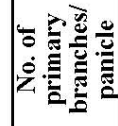 & 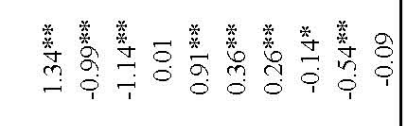 & 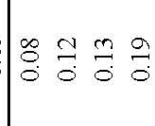 \\
\hline 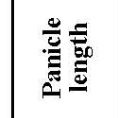 & 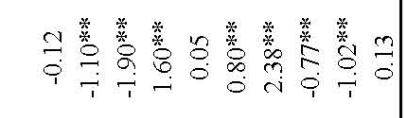 & กู \\
\hline 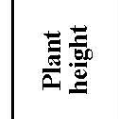 & 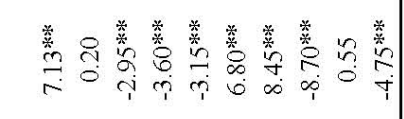 & $\stackrel{m}{\mathscr{\infty}} \stackrel{m}{=} \stackrel{2}{=}$ \\
\hline 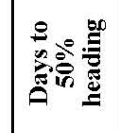 & 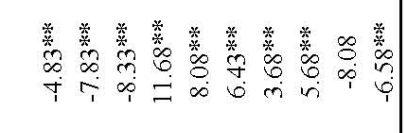 & $=\sqrt[n]{-\infty}$ \\
\hline 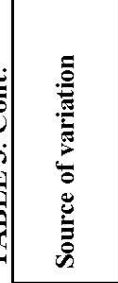 & 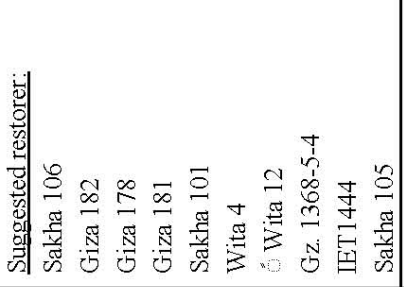 & 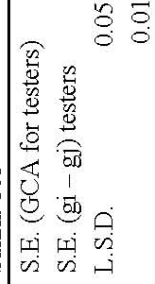 \\
\hline
\end{tabular}

Egypt. J. Agron. 35, No. 1 (2013) 
The previous results were, in general, harmony with those of Sundar \& Thiyagarajan (2002) and El-Keredy et al. (2007).

The results of combining method stated by Wang (1981) are presented in Table 4. Such results were obtained from the ranking numbers of GCA and according to the total marks; the evaluation of the parents was conducted. The results showed that among the CMS lines, G46 A and D297 A were the best general combiner. Among ten suggested restorer lines, Wita 12 ranked first, Giza 181 the second, Giza 178 the third while IET 1444 was in the end.

The results of SCA effects are presented in Table 5. Nine out of 40 hybrids showed significant or highly significant SCA effects with negative values for number of days to $50 \%$ heading, indicating that such hybrids were earlier than the others. G46 A $\times$ Giza 182 detected the highest negative SCA effects (-8.97; highly significant) for heading date.

Among 40 hybrids only Yimi $15 \mathrm{~A} \times$ Sakha 105 rice hybrid detected higher SCA effects with negative value (-19.44; Highly significant) for plant height compared with the other crosses. Such hybrid derived from parents with low $\times$ high GCA effects. Also, 10 other crosses showed highly significant negative value for SCA effects for plant height. While two other crosses showed significant value, but the rest crosses were either not significant or had positive SCA effects which are not of interest from plant breeder point of view. Most of desirable SCA effects for plant height derived from parents with high $\times$ low GCA effects.

Results in Table 5 showed that significant or highly significant positive SCA effects were detected for panicle length in ten hybrids. V20A $\times$ Sakha 106 rice hybrid recorded the maximum SCA value (2.71 \pm 0.45 ; highly significant). The desirable SCA effects for such trait resulted from parents with either high $\times$ high GCA effects ( 3 hybrids) or high $\times$ low GCA effects in (three hybrids) while, it resulted from low $\times$ low GCA effects in the remains hybrids.

17 out of 40 hybrid rice genotypes detected favorable SCA effects for number of spikelets/ panicle. Yimi $15 \mathrm{~A} \times$ Giza 178 showed the most desirable value of SCA effects $(40.03 \pm 0.16)$. 16 out of 40 crosses showed significant or highly significant positive SCA effects for fertility percentage. 18 hybrids recorded desirable SCA effects for number of filled grains/ panicle. Yimi 15A $\times$ IET1444 recorded the highest value of both fertility percentage $(45.97 \pm 1.63)$ and number of filled grains/ panicle $(87.37 \pm 1.95)$. Most of desirable SCA effects for the previous two traits were derived from parents with high $\times$ high GCA effects.

The favorable SCA effects for number of panicles/ plant were detected for 13 rice hybrids. V20A $\times$ Sakha 101 (high $\times$ high GCA effects) was the best combination followed by G46A $\times$ Sakha 106. Five out of these 13 hybrids resulted from parents with high $\times$ high GCA effects, 3 from parents with high $\times$ low GCA effects and 5 from parents with low $\times$ low GCA effects. 


\begin{tabular}{|c|c|c|}
\hline 竘 & $\stackrel{n i n}{-i} m+$ & 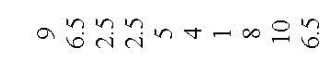 \\
\hline$\stackrel{5}{\frac{\pi}{0}}$ & तีतै लै & 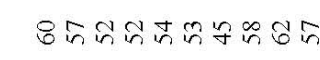 \\
\hline 苞焉 & $n-\forall m$ & 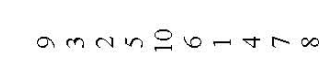 \\
\hline 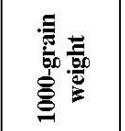 & $N m-\nabla$ & $\operatorname{tmn}-N \infty a 90+$ \\
\hline 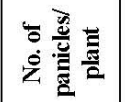 & $\nabla m n-$ & $a r n g-n b+n \infty$ \\
\hline 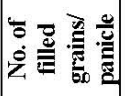 & $-n+m$ & $a \tan \cong 0-\operatorname{mos}$ \\
\hline 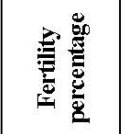 & $m-\nabla c$ & $a m n+\subseteq \sigma-m n$ \\
\hline 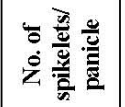 & $-d \forall m$ & r@ \\
\hline 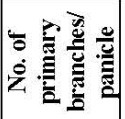 & $\neg \mathrm{d} \nabla$ & 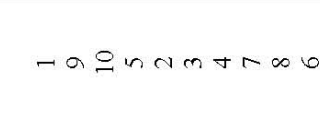 \\
\hline 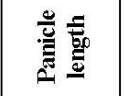 & $-m+a$ & $609 \pi \sin m-n+\infty$ \\
\hline 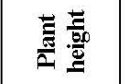 & $m \sim \nabla-$ & abnm $\operatorname{ta} \varrho-n n$ \\
\hline 象最 & $+m-c$ & $n m-90 \infty 6 n+4$ \\
\hline 旡 & 氛| & 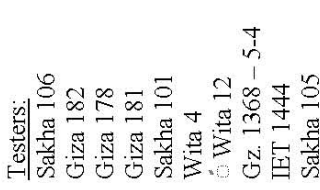 \\
\hline
\end{tabular}

Egypt. J. Agron. 35, No. 1 (2013) 
GENETIC ANALYSIS OF SOME CYTOPLASMIC...

\begin{tabular}{|c|c|}
\hline 踣 & 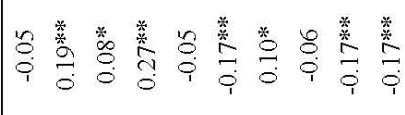 \\
\hline 高言章 & 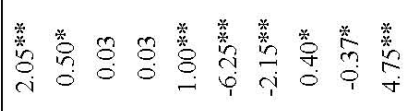 \\
\hline 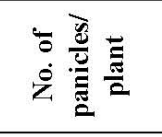 & 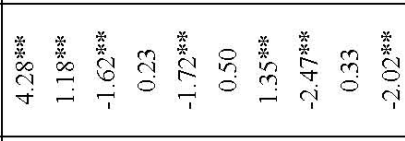 \\
\hline 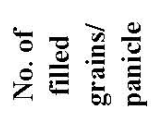 & 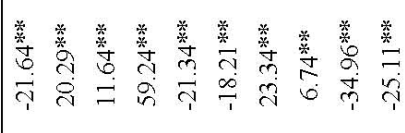 \\
\hline 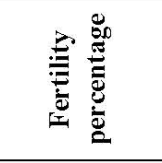 & 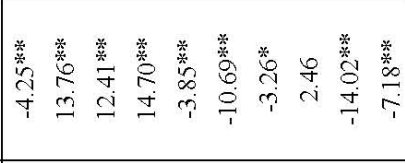 \\
\hline 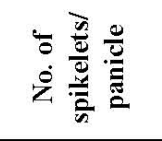 & 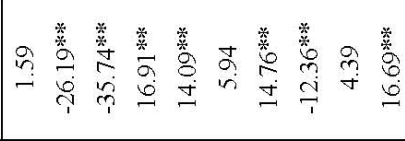 \\
\hline 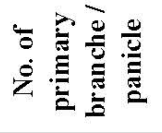 & 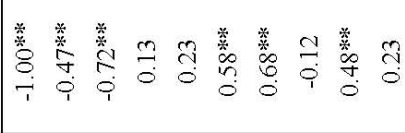 \\
\hline 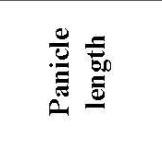 & 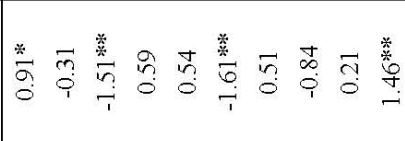 \\
\hline$\frac{E}{\stackrel{E}{E}}$ & 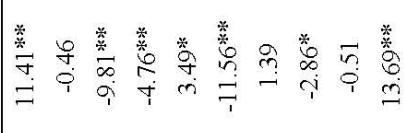 \\
\hline 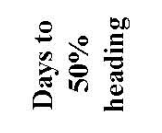 & 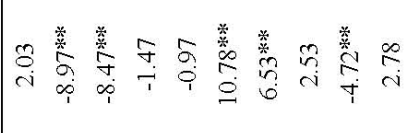 \\
\hline 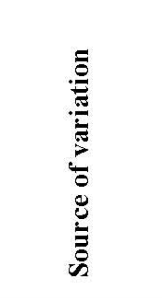 & 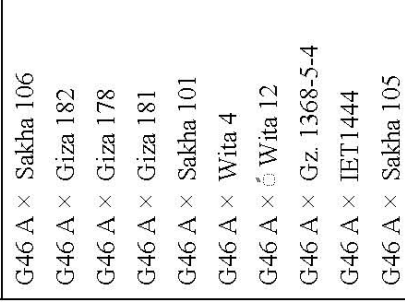 \\
\hline
\end{tabular}

Egypt. J. Agron. 35, No. 1 (2013) 


\begin{tabular}{|c|}
\hline 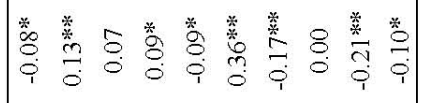 \\
\hline 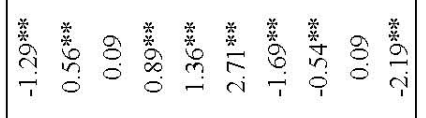 \\
\hline 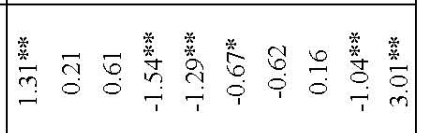 \\
\hline 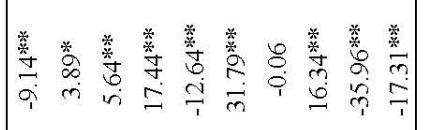 \\
\hline 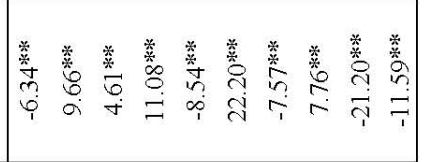 \\
\hline 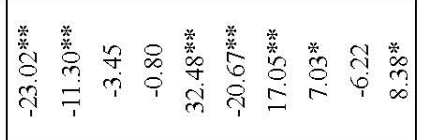 \\
\hline 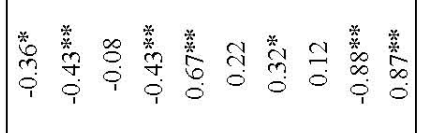 \\
\hline 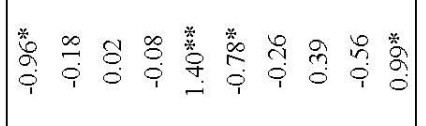 \\
\hline 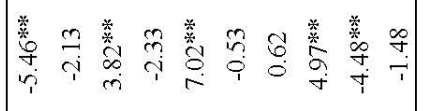 \\
\hline 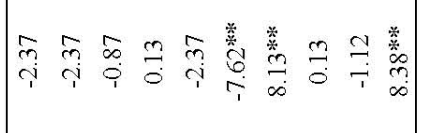 \\
\hline 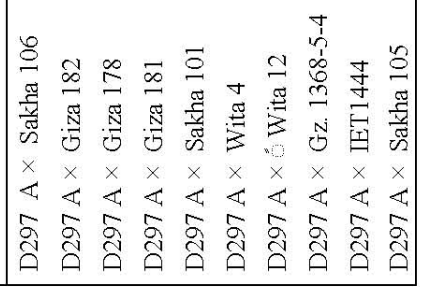 \\
\hline
\end{tabular}

Egypt. J. Agron. 35, No. 1 (2013) 
GENETIC ANALYSIS OF SOME CYTOPLASMIC...

\begin{tabular}{|c|c|}
\hline & 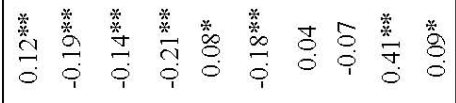 \\
\hline$\stackrel{\circ}{\circ}$ & 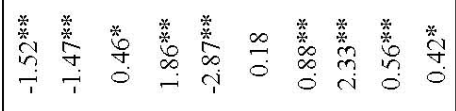 \\
\hline 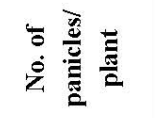 & 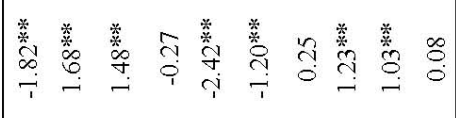 \\
\hline 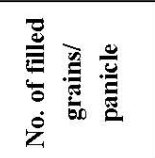 & 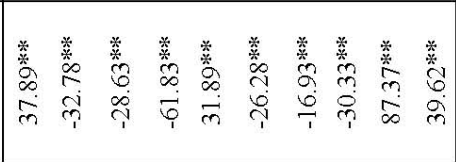 \\
\hline 嘅 & 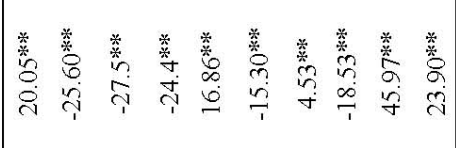 \\
\hline 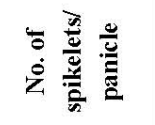 & 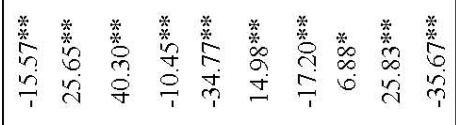 \\
\hline 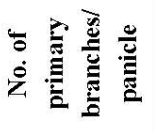 & 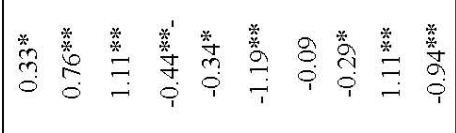 \\
\hline 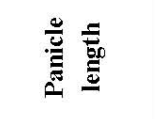 & 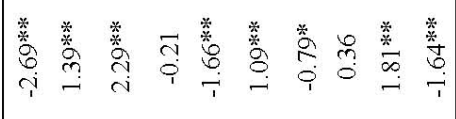 \\
\hline$\frac{E}{\frac{E}{E}}$ & 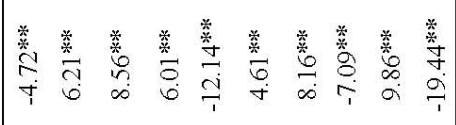 \\
\hline 党 & 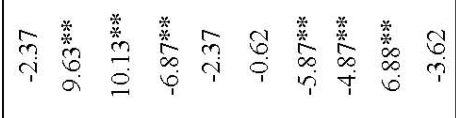 \\
\hline 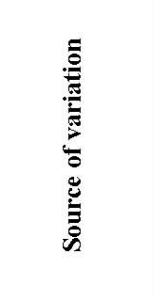 & 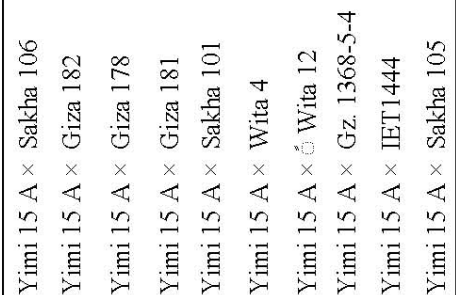 \\
\hline
\end{tabular}

Egypt. J. Agron. 35, No. 1 (2013) 


\begin{tabular}{|c|c|c|}
\hline 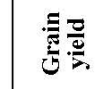 & 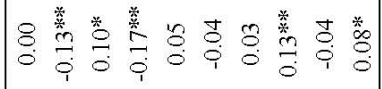 & 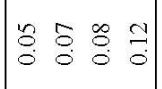 \\
\hline s: & 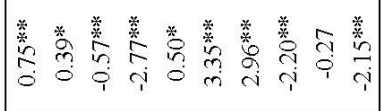 & तิ \\
\hline 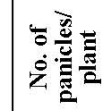 & 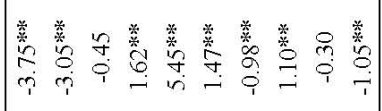 & 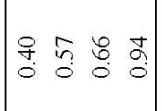 \\
\hline 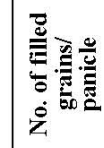 & 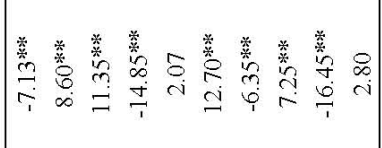 & 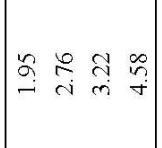 \\
\hline 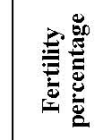 & 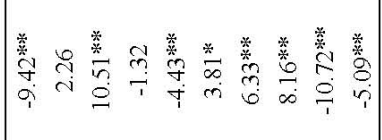 & 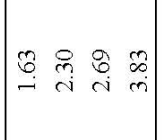 \\
\hline 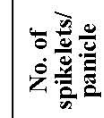 & 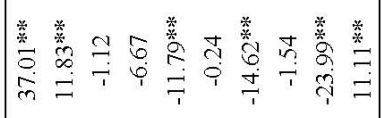 & $\mid \begin{array}{llll}9 & 9 & 2 & \overline{0} \\
+ & 5 & 0 & 0\end{array}$ \\
\hline & 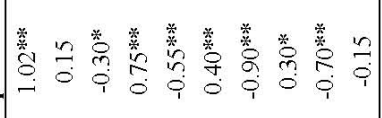 & 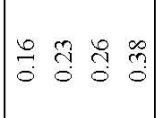 \\
\hline 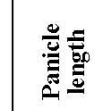 & 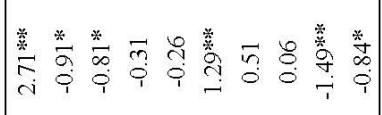 & 鹪突 \\
\hline 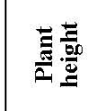 & 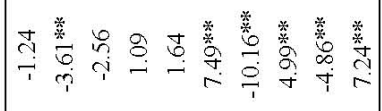 & 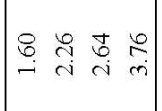 \\
\hline 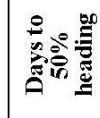 & 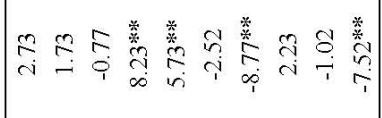 & 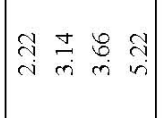 \\
\hline 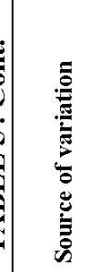 & 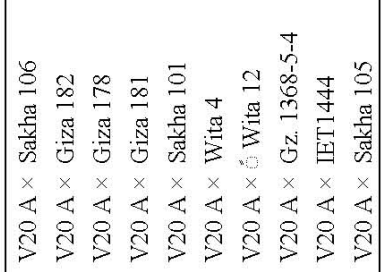 & 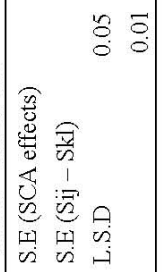 \\
\hline
\end{tabular}


Among 40 rice hybrids only 19 ones showed significant or highly significant positive SCA effects for 1000- grain weight. Such estimates ranged from $0.39 \pm$ 0.22 to $4.75 \pm 0.22$ for the crosses V20A $\times$ Giza 182 and G46A $\times$ Sakha 105 , respectively. The best hybrid rice combination $(G 46 A \times$ Sakha 105$)$ derived from parents possess low $\times$ high GCA effects. So, crosses between high general combiners did not always resulted in the best combination (Shirvastana \& Seshu, 1983). Most of desirable SCA effects for 1000-grain weight were resulted from parents with high $\times$ low GCA effects.

Results presented in Table 5 showed that 13 out of 40 hybrids showed significant or highly significant positive SCA effects for grain yield. G46A $\times$ Giza 182, G46A $\times$ Giza 181, D297A $\times$ Wita4 and Yimi 15A $\times$ IET 1444 were the best general combiners for grain yield.

Generally, crosses showing high SCA effects for grain yield involved parents of high or low GCA value. The combinations that show high SCA effects for grain yield also showed high SCA effects for one or more of yield components. For example, G46A $\times$ Giza 182 which showed high SCA effects for grain yield also showed high SCA estimates for 1000-grain weight, number of panicles/ plant, number of grains/ panicle and fertility percentage. Such results were in agreement with those reported by Hammoud et al. (2008). So, one or more of these hybrids might be incorporated in hybrid rice breeding program for grain yield improvement.

\section{Genetic parameters}

Narrow sense heritability is very important so, it takes into account before starting any breeding program. It expresses about the portion of the total variance that is due to heredity factors, especially the additive gene action. The estimates of additive variance $\left(\sigma^{2} \mathrm{~A}\right)$, dominance variance $\left(\sigma^{2} \mathrm{D}\right)$, genotypic variance $\left(\sigma^{2} \mathrm{G}\right)$, genotypic coefficient of variability $(\mathrm{GCV})$, narrow sense heritability $\left(\mathrm{h}^{2} \mathrm{~ns}\right)$, genetic advance from selection $(\Delta \mathrm{g}), \Delta \mathrm{g} \%$ (as a percent of mean), relative importance of GCA and relative importance of SCA for all the studied traits are presented in Table 6.

The estimates of additive variance $\left(\sigma^{2} \mathrm{~A}\right)$ as well as the relative importance of GCA for number of days to $50 \%$ heading, number of panicles/ plant and 1000 grain weight were higher than the dominance variance $\left(\sigma^{2} \mathrm{D}\right)$ and the relative importance of GCA, indicating that the additive genetic variance was more important in the inheritance of these traits. The importance of additive gene action for the inheritance of these traits was in agreement with the previous results of Sharma \& Koranne (1995).

Vice-versa, the dominance variance $\left(\sigma^{2} \mathrm{D}\right)$ and the relative importance of SCA were higher for the remaining characters, indicating that the dominance gene action was predominated in the inheritance of such traits. These results were, in general, agreement with those reported by Dwivedi \& Pandey (2012). Similar results were also obtained by Gautam et al. (2012). They reported that the non-additive gene action was more important than the additive one in the inheritance of 5 traits including grain yield, spikelet fertility and number of spikelets/ panicle. 


\begin{tabular}{|c|c|}
\hline 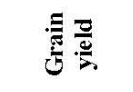 & 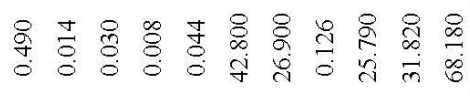 \\
\hline 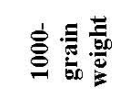 & 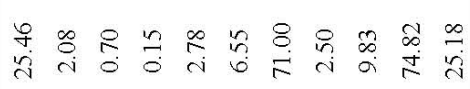 \\
\hline 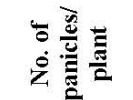 & 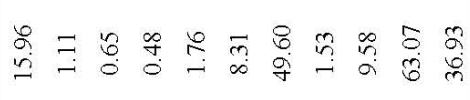 \\
\hline 就产竞 & 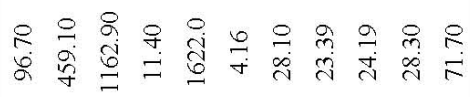 \\
\hline 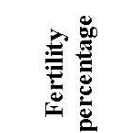 & 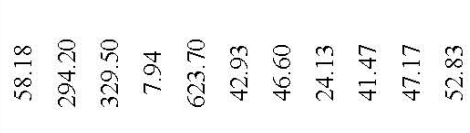 \\
\hline 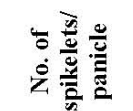 & 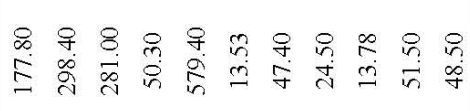 \\
\hline 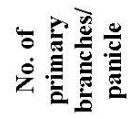 & 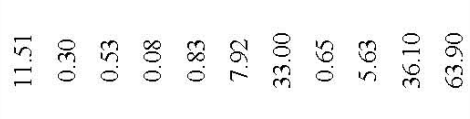 \\
\hline 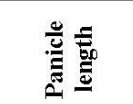 & 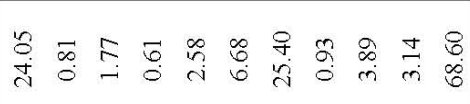 \\
\hline 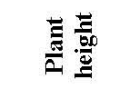 & 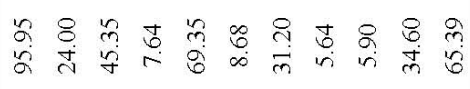 \\
\hline 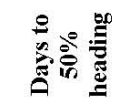 & 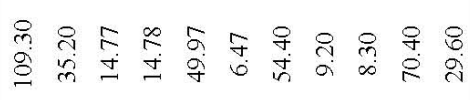 \\
\hline 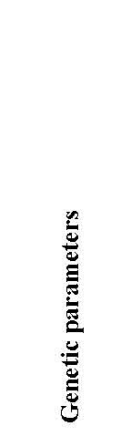 & 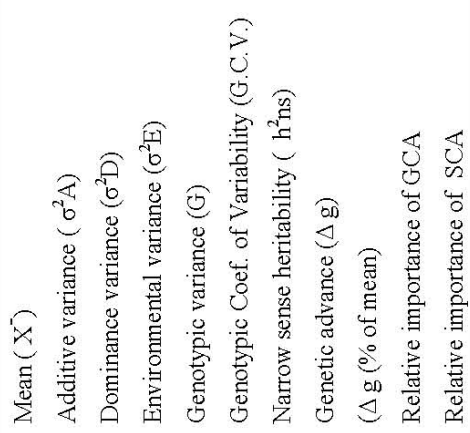 \\
\hline
\end{tabular}

Egypt. J. Agron. 35, No. 1 (2013) 
Wide range of genetic variability was detected among rice genotypes for all the studied characters. Fertility percentage and grain yield recorded the highest genotypic coefficients of variability; 42.93 and 42.8 , respectively. Indicating that these traits might be more genotypically predominated and it is possible to achieve further improvement from them. While, the other character had moderate or low amount of variability. Previous study showed that grain yield per plant had high genotypic coefficients of variability (Choudhary \& Das, 1998). Similar results were also obtained by Devi et al. (2006). Previous results showed that the highest genotypic coefficients of variation were detected for sterility percentage followed by grain yield (Mehetre et al., 1996).

Heritability estimates in narrow sense were relatively high for 1000 -grain weight $(0.71)$ and number of days to $50 \%$ heading $(0.54)$ while, it was relatively moderate for number of spikelets/ panicle (47.4) and fertility percentage (46.6) but low narrow sense heritability estimates were recorded for the remaining characters including grain yield (26.9). These results were in general agreement with those reported by Abdel-Hafez et al. (1992) who found that 1000-grain weight, heading date and fertility percentage had high narrow sense heritability, while it was moderate for number of filled grains/ panicle. Estimates of narrow sense heritability were high for days to heading while, it was moderate for number of spikelets/ panicle and low for grain yield (Surek \& Korkut, 1998).

The genetic advance under selection is presented in Table 6 . The expected genetic advance $(\Delta \mathrm{g} \%)$ from selection, as a percentage of mean, was high for fertility percentage (41.47) and number of filled grains/ panicle (24.19). Such high value may be interpreted that some of the parent detected high fertility percentage in their crosses (good restorers) and some detected moderate fertility percentage (partial or weak restorers) and some of them detected low fertility (good maintainers). So, the value of fertility percentage depends largely upon the selected parents, therefore the improvement of these traits through selection is the most important way to achieve further improvement.

Relatively moderate values of $(\Delta \mathrm{g} \%)$ were recorded for grain yield (25.79) and number of filled grains/ panicle (24.19). While, the other characters detected low estimates of genetic gain from selection. The aforementioned results were, in general, harmony with those reported by Jakkrit et al. (2013). They found that number of fertile grain/ panicle and number of spikelets/ panicle revealed the highest genetic advance from selection.

High heritability along with high genetic advance was registered for fertility percentage and number of spikelets/ panicle (Ghosh \& Sharma, 2012). High heritability coupled with moderate gain from selection was observed for days to flowering and plant height (Uttam et al., 2005). The high heritability estimates is not always associated with high genetic gain. In this study the desirable genetic gain was found to be associated with moderate narrow sense heritability in case of fertility percentage and number of spikelets/ panicle. Low heritability 
estimates coupled with low genetic advance were recorded for panicle length and grain yield (Sedeek et al., 2007). High genetic advance combined with high genotypic coefficients of variation $(\mathrm{GCV})$ and high heritability were recorded for number of filled grains/ panicle and number of spikelets/ panicle (Basak \& Ganguli, 1996).

\section{Conclusion}

Based on the previous results, selection strategy for each of the studied traits can be performed. Choosing the dooner parents could be applied in hybridization programs for grain yield improvement. The value of spikelet fertility of $F_{1}$ hybrid rice depends largely upon the pollen parent. Crosses which show high SCA for grain yield also show high SCA for one or more of yield components. Fertility percectage and grain yield detected relatively higher GCV estimates indicating that these traits might be more genetically predominated and it is possiblle to acheive further improvement in them.

Acknowledgment : Many thanks and gratitude are due to Prof. M.S. El-Keredy for his kind help and encouragement.

\section{References}

Abdel-Hafez, A.G., El-Keredy, M.S. and El-Mowafy, H.F. (1992) Genetic components and heritability in rice. Proc $5^{\text {th }}$ Con. Agron., Zagazig Univ. 1, 216-225.

Basak, A.K. and Ganguli, P.K. (1996) Variability and correlation studies on yield and yield components in induced plant type mutants of rice. Indican Agriculturist , 40 (3), 171-181.

Borton, G.W. and Devan (1953) Estimating heritability in tall fescue (Festuca arundianacea) from replicated clonal material. Agron. J. 45, 478-481.

Choudhary, P.D. and Das, P.K. (1998) Genetic variability and correlation between quality and physio-chemical properties of high grain quality in rice. Chinese J. Rice Sci. 11 (2), 70-76.

Devi, L.S., Raina, F.A., Pandey, N.K. and Kole, C.R. (2006) Genetic parameters of variation for yield and its components in rice (Oryza sativa L.). Crop Research Hisar, 32 (1), 69-71.

Dwivedi, D.K. and Pandey M.P. (2012) Gene action and heterosis for yield and associated traits in indica and tropical japonica crosses of rice (Oryza sativa L.) involving wide compatibility gene (s). International Journal of Plant Breeding and Genetics, 6, 140-150.

El-Degwy, I.S. (2000) Studies on hybrid rice breeding. M.Sc Thesis, Fac. Agric., Kafr Elsheikh, Tanta Univ., Egypt.

Egypt. J. Agron. 35, No. 1 (2013) 
El-Keredy, M.S., El-Weheishy, M., El-Degwy, I.S. and Tan, X.L. (2007) Identifying maintainers and restorers of some Chinese cytoplasmic male sterile (CMS) lines for hybrid rice breeding. Proc $8^{\text {th }}$ African Science Conference, El-Menia, 27 $7^{\text {th }}-31^{\text {th }}$ October, Egypt.

El-Keredy, M.S., El-Weheishy, M., El-Degwy, I.S. and Tan, X.L. (2008) Combining ability of some hybrid rice varieties with Chinese-bred cytoplasmic male sterile (CMS) lines. J. Agric. Res. Kafr Elsheikh Univ. 34 (1), 11-24.

Gautam, R.K., Sekhon, R.S. and Bharaj, T.S. (2012) Commercial heterosis and combining ability in rice (Oryza sativa L.) hybrids involving bacterial blight resistance and susceptible cytoplasmic male sterile lines. Tropical Agriculture, 89 (1), 25.

Ghosh, S.C. and Sharma, D. (2012) Genetic parameters of agromorphophysiological traits in rice (Oryza sativa L.). International Journal of Plant Breeding and Genetics, 3 (1), 711-714.

Gluzar, S. and Waseem H. (2012) Heterosis and combining ability estimates using Line $\times$ Tester analysis to develop rice hybrids for temperate conditions. Notulae Scientia Biologicae , 4 (3).

Hammoud, S.A.A. (2004) Inheritance of some Quantitative characters in rice. Ph.D Thesis, Fac. Agric. Menufeya Univ., Shibin El-Kom, Egypt.

Hammoud, S.A.A., El-Degwy, I.S., Sedeek, S.E.M. and Zayed, B.A. (2008) Line $\times$ Tester analysis for some quantitative traits in rice. Proc. of the Second Field Crop Conf., FCRI, ARC, Giza, Egypt, $14^{\text {th }}-16^{\text {th }}$ Oct.

Hossein, S., Atefeh, S., Reza, K., Mahnaz, K. and Ahmed, R.D. (2013) Genetical analysis of agronomic traits in rice (Oryza sativa L.). International Journal of Agronomy and Plant Production , 4 (6), 1298-1304.

Jakkrit, S., Prapa, S., Pornpen, S. and Tanee, S. (2013) Genotypic correlation and path coefficient for some agronomic traits of hybrid and inbred rice (Oryza sativa L.) cultivars. Asian Journal of Crop Science , 5 (3), 319-324.

Johnson, H.W., Robinson, H.F. and Comstock (1955) Estimates of genetic and environmental variability in soybean. Agron. J. 47, 314-318.

Kempthorne, O. (1957) "An Introduction to Genetic Statistics". XVII, John Wiley and Sons Inc., New Yourk. 545pp.

Mehetre, S.S., Patil, A.P., Mahajan, R.C. and Shinde, B.R. (1996) Variability, heritability, character association and genetic divergence studies in M2 generation of gamma irradiation upland paddy. Crop Research Hisar, 12 (2), 27-33.

Mehla, J.S., Singh, S. and Panwar, D.V.S. (2000) Combining ability studies for yield and its components in rice hybrids involving wild abortive (WA) source of CMS line. Agric. Sic. Digest. 20 (3), 146-149. 
Onyia, V.N. (2012) Combining ability analysis for yield and yield components in eight breeding lines of rice (Oryza sativa L.). Journal of Tropical Agriculure, Foods, Environment and Extension, 10 (2).

Padmavathi, P.V., Satyanarayana, P.V., Ahmed, M., Rani, Y. and Rao, V. (2012) Combining ability studies for yield and yield components trait in hybrid rice (Oryza sativa L.). Electronic Journal of Plant Breeding , 3 (3), 836-842.

Roy, S.K. and Senapati, B.K. (2012) Combining ability analysis for grain yield and quality characters in rice (Oryza sativa L.). The Indian Journal of Agricultural Sciences, 82 (4).

Sedeek, S.E.M., Hammoud, S.A.A., El-Abd, A.B. and El-Rewainy, I.O. (2007) Generation mean analysis of some agronomic traits, blast diseases and stem borer resistance in two rice crosses under two N - levels. J. Plant Breed. 11 (2), 563-580.

Sharma, R.K. and Koranne, K.D. (1995) Line $\times$ Tester analysis for yield and yield components in Indica $\times$ Japonica crosses of rice. Oryza, 32, 234-238.

Shrivastava, M.N. and Seshu, D.V. (1983) Combining ability for yield and associated characters in rice. Crop Sci. 23, 741-744.

Sundar, S. and Thiyyagarajan, K. (2002) Combining ability of rice hybrids for yield and yield components. Research on Crops, 3 (3), 615-619.

Surek, H. and Korkut, K.Z. (1998) Diallel analysis of some quantitative characters in F1 and F2 generations in rice (Oryza sativa L.). Egypt J. Agric. Res. 76 (2), 651-663.

Uttam, C., Katoch, C.P. and Vijay, K. (2005) Viability studies in some macromutations induced by EMS and gamma rays in Basmati rice T-23. Annals of Biology, 21 (2), $137-141$.

Wang, R.C. (1981) Preliminary studies on heterosis and combining abilits in hybrid rice (Oryza sativa L.). Zhejiang Agric. Sci. 5, 205-212.

Yuan, L.P. (1994) Increasing yield potential in rice by exploitation of heterosis. In: "Hybrid Rice Technology; New Development and Future Prospects", Virmani, S.S. (Ed.). International Rice Research Institute, Manila, Phillipins. 
التحليل الوراثي لبعض السلالات العقيمة ذكريا وسلالات معيدة للخصوبة فى الأرَز

إبراهيم سعد الاجوى الإي قسم المحاصيلـ كلية الزراعة- جامعة كفر الثيخ- كفر الثيخ- مصر .

اجري هذا البحث بالمزرعة التجريبية بكلية الزراعة- جامعة كفر الثيخ- خلال

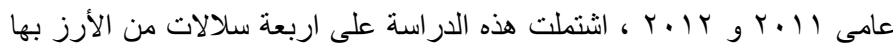

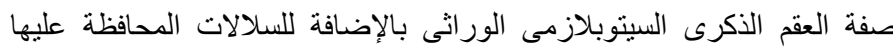

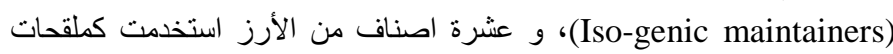

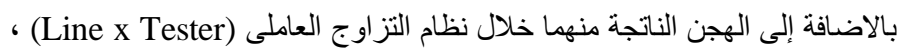

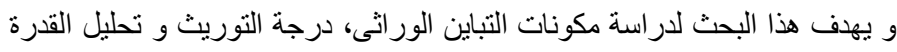

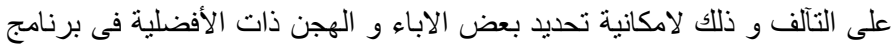

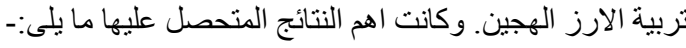

أظهرت النتائج ان الفعل المضيف للجين و الأهمية النسبية لتباين القدرة

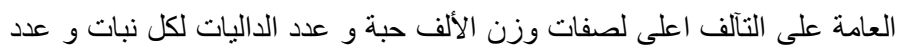

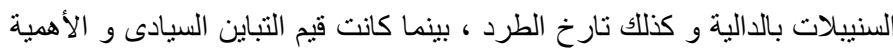

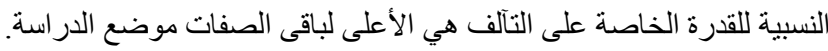

سجلت السلالة G46A و السلالة D297A و الاصناف

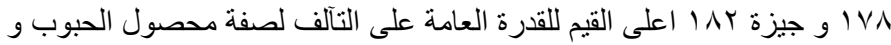

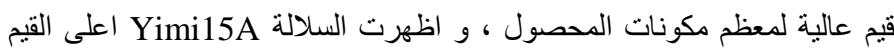

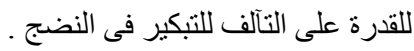

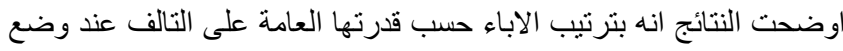

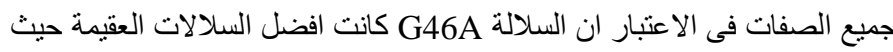
احتلت المركز الأول ، فى حين سجل الصنف الصن Wita12 المرتبة الأولى بالنسبة لاصناف الملقحة.

سجلت صفات محصول الحبوب و نسبة الخصوبة و عدد السنيبلات بالدالية

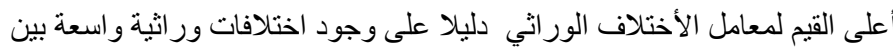

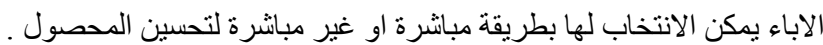

كانت قيم المكافئ الور اثى بالمفهوم الضيق عالية نسبيا لصفات تار خ الطرد و

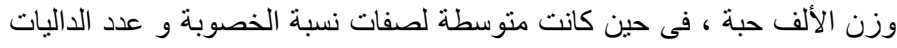
لكل نبات و عدد السنيبلات بالدالية و منخفضة بالن بالنسبة لباقى الصفات. 
سجلت صفات نسبة الخصوبة وعدد الحبوب الممتلئة بالدالية و محصول الحبوب اعلى القيم لمقدار التحسين الور اثى المتوقع بالأنتخاب.

اوضحت النتائج ان الهجن D297A x Wita 4 و G46A x Giza181 و G46A x Giza182 كانت من الهجن المتميزة فى قدرتها على التآلف لصفة

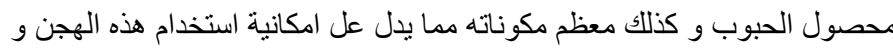

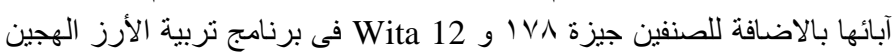

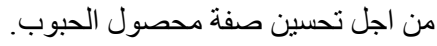

